\title{
Gender Differences in Academic Performance in a Large Public University in Turkey
}

\author{
Meltem Dayığlu \\ Department of Economics \\ Middle East Technical University \\ Ankara 06531 Turkey \\ dmeltem@metu.edu.tr \\ Serap Türüt-Aşık \\ Department of Economics \\ Middle East Technical University \\ Ankara 06531 Turkey \\ sturut@metu.edu.tr
}




\title{
Gender Differences in Academic Performance
}

\section{in a Large Public University in Turkey}

\author{
Meltem Dayığlu*
}

and

Serap Türüt-Aşık

\begin{abstract}
The paper attempts to determine whether there are significant gender differences in academic performance among undergraduate students in a large public university in Turkey based on three indicators; university entrance scores, performance in the English preparatory school and in the program the student is majoring in. The paper finds that a smaller number of female students manage to enter the university and when they do so, they enter with lower scores. However, once they are admitted to the university, they excel in their studies and outperform their male counterparts. This result holds after controlling for the field of study and individual attributes.
\end{abstract}

Keywords: Academic achievement, undergraduate students, gender disparity, Turkey

* Corresponding author 


\section{Introduction}

The paper attempts to determine whether there are significant gender differences in academic performance among undergraduate students at Middle East Technical University (METU), which is a large public university in Turkey, and if so, the factors that give rise to these differences. Academic performance is affected by a host of factors. These include individual and household characteristics such as student ability, motivation, the quality of secondary education obtained and the like. The gender of the student may also be a factor in determining student performance. Childhood training and experience, gender differences in attitudes, parental and teacher expectations and behaviors, differential course taking and biological differences between the sexes may all be instrumental in giving rise to gender differences in achievement (Feingold, 1988). The rather high gender disparity in various spheres of public life and the patriarchal social structure in Turkey may also lead to poorer academic performance among female university students.

In terms of educational attainment women lag behind men in Turkey. The 2000 Population Census records the illiteracy rate among men at $6.1 \%$, while that of women at 19.4\% (SIS, 2003). Among the literate population, men's average level of schooling far exceeds that of women though there does seem to be a faster improvement among the latter (Dayığlu and Tunalı, 2002). Gender disparity in schooling is also observed among the younger population, where female school enrollment in basic and secondary education falls behind male children (Tansel, 2002; Ertürk and Day1oğlu, 2004). Despite the numerous studies that analyze the disadvantaged position of women as adults and children, there is almost no work on the educational experiences of women as young adults. The paucity of such work has been one of the motivations for this study. The other motivation has been our observation that in the undergraduate classes we teach female students often outperform their male counterparts. This casual observation contradicts with the general experiences of the female population as children and adults. Hence, this study grew out of 
our curiosity to find out how far our personal observations hold for the general undergraduate student population in our university.

Following the introduction, the study is organized as follows: Section 2 looks at the literature on gender differences in scholastic achievement. Section 3 presents a brief account of the education system in Turkey and gives information about Middle East Technical University. Section 4 presents the employed methodology, while Section 5 discusses the data set used. Section 6 presents the results on student academic achievement and compares the performance of male and female students on the basis of a number of indicators. Section 7 concludes the paper.

\section{Review of literature}

Despite the lack of interest in Turkey, numerous studies on sex differences in cognitive performance can be found in the literature. In one of the earliest studies Morris (1959) referring to the psychic and social differences between sexes, claims that the education outcomes of men and women will, at least in part, be different at the collegiate and graduate level. The debate on gender differences in cognitive abilities has actually evolved out of the debate on biological vs. social determinism. The biological perspective on sex differences and cognitive performance considers social factors to be trivial or subordinate to biological factors like brain structure. Lynn in several of his studies (Lynn, 1998a, 1998b, 1999; Allik, Must and Lynn, 1999; Colom and Lynn, 2004) asserts that males have larger average brain sizes than females and therefore, would be expected to have higher average IQs ${ }^{1}$. Mackintosh (1998), on the other hand, claims that there is no sex difference in general intelligence. Mackintosh proposes that general intelligence should be

\footnotetext{
${ }^{1}$ General intelligence is defined as the sum of verbal comprehension, reasoning and spatial abilities.
} 
defined as reasoning ability and that the best measure of this is the Progressive Matrices. ${ }^{2}$ Examining two tests administered by The Israeli Defense Forces which qualify as IQ tests one of them is an adaptation of Progressive Matrices- Flynn (1998) finds no sex difference. Investigating academic performance at pre-collegiate level, Lao (1980) finds female students to obtain higher CGPA compared to males. Examining sex-related difference in classroom grades, Kimball (1989) finds that in contrast to standardized measures of mathematics achievement tests like SAT-M ${ }^{3}$, female students outperform males in math classes. Wilberg and Lynn (1999) arrive at a similar conclusion for history classes vs. history tests. The authors explain this pattern by stating that females tend to work more conscientiously and have a stronger work ethic than males. They also tend to have better language abilities including essay writing skills, vocabulary and word fluency which contribute to better course work. Stage and Kloosterman (1995) note that although gender differences in math achievement continue to exist on high cognitive level tasks at the high school level, such differences appear to be declining. Young and Fisler (2000) examining SAT-M scores of high school seniors, find males to score better than females. However, they note that males generally come from households where the parents' socioeconomic status as measured by examinee reported educational levels and income, is higher. In contrast, female test takers are more diverse and include more low-income students than the boys group. Others have argued that the content of the test or of its administration favors males (Bridgeman and Wendler, 1991). Yet other researchers have explained the gap by adhering to such factors as differences in course taking behavior, classroom experiences and cognitive processing (Byrnes, Hong and Xing, 1997; Young and Fisler, 2000).

\footnotetext{
${ }^{2}$ The Standard Progressive Matrices was constructed in the late 1930s as a test of non-verbal or abstract reasoning ability and the Advanced Progressive Matrices was constructed in 1947 as a more difficult version of the test suitable for those in the higher ability range (Lynn and Tse-Chan, 2003).

${ }^{3}$ SATs were revised and renamed as the Scholastic Assessment Tests (SAT I) and Scholastic Achievement Tests (SAT II) (Young and Fisler, 2000; Leonard and Jiang 1999).
} 
The studies conducted outside of the US present differing outcomes. Younger, Warrington and Williams (1999) focus on the gender gap in English secondary schools. Their analysis is based on the performance of boys and girls in GCSE examinations in the UK and girls are found to get better grades than boys. This phenomenon is explained by boys' disregard for authority, academic work and formal achievement, differences in students' attitudes to work and their goals and aspirations and girls' increased maturity and more effective learning strategies. Baker and Jones (1993) analyze sex differences in the eighth grade math performance of over 77,000 students in 19 developed and developing countries. They find no evidence of a significant gender gap. Both cross-national variation in sex differences in mathematical performance and the trend toward less of a difference between males and females question any innate male superiority in intelligence. OECD (2001) analyzes gender differences in mathematics and science achievement in the eighth grade for fourteen OECD countries including Turkey. The study finds that gender differences in mathematics achievement are statistically insignificant in all countries but the Czech Republic. In science, gender differences favor males and are often statistically significant except for five countries including Turkey.

In higher education women are often found to outperform men. Hyde and Kling (2000) state this to be the case irrespective of the measure of success used. Betts and Morell (1999) report that sex remains a significant predictor of CGPA after controlling for various individual attributes such as ethnic background, SAT scores and the high school attended. Similarly, investigating about 60,000 students from 22 public research universities, Kim, Rhoades and Woodard (2003) find that SAT scores have a significant impact on student graduation, although at the individual level gender is a more powerful correlate of graduation than the SAT score. Women are also found to obtain better grades than would be predicted from their SAT scores (Leonard and Jiang, 1999; Hyde and Kling, 2001; Bridgeman and Wendler, 1991; Wainer and Steinberg, 1992). Many researchers 
claim that a large part of the under-prediction derives from the difference in course taking patterns of male and female college students. Ruling out differential course selection as an explanation for the under-prediction of female grades, Leonard and Jiang (1999) suggest that females have better study skills than the male students. Other researchers have argued that women receive higher grades than men because they work harder and attend class more frequently (Wainer and Steinberg, 1992).

Investigating success in terms of course grades, Bridgeman and Wendler (1991) find that women typically had equal or higher grades in math classes. Wainer and Steinberg (1992) on a sample of 62,000 students conclude that although women had lower SAT-M scores, they received similar grades from first-year math courses. Cohn et al. (1998), on the other hand, find gender to an insignificant determinant of success in courses on macroeconomics.

The literature survey on gender differences in scholastic performance at different levels indicate mixed results. However, one common finding is that females outperform their male counterparts in higher education. In what follows next, we shall try to see whether this is also true for Turkey.

\section{Education system in Turkey and at METU}

The formal education system in Turkey includes basic education, secondary education and higher education institutions. Basic education is compulsory and lasts for eight years. Secondary education, on the other hand, is composed of general, and technical and vocational high schools. General high school education last for three years, while technical and vocational training may extend up to four years. While the former is geared more toward preparing students for tertiary education, the latter aims to equip students with marketable skills for immediate employment after graduation. The curricula of vocational and technical schools differ depending on the type of vocational training they offer. The 
curricula of general high schools may also differ from each other; while some schools emphasize mathematics and sciences in their teachings, in others the emphasis is on foreign languages with the medium of instruction being in a foreign language. A significant proportion of these specialized public high schools admit students through a centralized exam. The overwhelming majority of basic and secondary education schools (including the specialized high schools) are public and free of charge though the parents are expected to meet various school expenses such as books, school supplies, commuting fees etc. The proportion of the student population enrolled in private basic and secondary schools is limited to $1.5 \%$ (MNE, 2004).

\subsection{Progression to higher education}

Admittance to higher education is through a central examination managed by the Student Selection and Placement Center. The university entrance exam is given once a year and over 1.5 million high school graduates take it annually. The applicants get placed into the departments and universities of their choice depending on their placement score which includes the examination score along with the high school CGPA of the student. The latter is weighted by the standing of the student's school in the placement exam. Following the exam, the student submits to the Placement Center a list containing his/her department and university preferences. Depending on the score obtained, s/he may get placed into any one or none of his/her submitted choices as placement starts from the applicant with the highest score and moves down until the allocated slots for each department is filled. The minimum score above which a department in a given university admits students may change from one year to the next depending on the demand for the department in that specific university and the available seats. Medical schools and engineering departments are usually high in demand requiring top scores. At the other end of the spectrum, there are open-university programs that require much lower scores for admittance. The scores of more established 
universities are also comparatively higher. Although there are 53 public and 24 private universities $^{4}$ scattered around the country vast difference in the quality of higher education offered causes excess demand for more established universities. On a yearly basis, roughly one out of ten applicants gets placed into a four-year program. An additional $20 \%$ are placed into open-university or two-year programs (SSPC, 2004). The success rate is slightly lower for the first time applicants (44\%) who often end up taking the exam a number of times before they get placed (T.C. Yükseköğretim Kurulu, 2003). The problem associated with not being placed into a program of choice lies in the imbalance between the demand for and supply of higher education. Despite the high demand, limited capacity causes university graduates to constitute a small proportion of the population. Among the adult population those with higher education, inclusive of open-university, is limited to $6 \%$ (SIS, 2003). This figure is lower for women recorded at $4.9 \%$.

The university entrance exam has taken on such a paramount importance in the lives of the young people that many devote a good part of their last two years in high school preparing for this examination. In fact, the struggle starts earlier in trying to get into a high school that is reputed to succeed in getting the largest number of students placed in prestigious universities. But the struggle hardly ends there. Besides following the high school curriculum, students attend specialized private courses geared toward preparing them for the university examination during their high school years. The cost of such private courses is often rather high. The end result is that the chances that a young adult of modest background will enter a highly competitive university are rather slim.

\subsection{Middle East Technical University}

Middle East Technical University (METU), located in the capital city of Ankara, is one of the larger public universities in Turkey with nearly 14,500 undergraduate and 5,200

\footnotetext{
${ }^{4}$ More information on universities in Turkey can be obtained from http://www.yok.gov.tr.
} 
graduate students, and 700 faculty members (METU, 2003). It was established in 1956 by an American mission and therefore, the education system shares many common features with American universities. It operates on a semester system. Students obtain credits from the courses they take and graduation is conditional on obtaining the required amount of credits from a minimum number of courses within a maximum of 14 semesters. Being a public university the tuition fee is relatively low ranging from $\$ 240 /$ year in the Faculty of Education to $\$ 650 /$ year in the Faculty of Architecture. ${ }^{5}$ Students who do not have the financial capability of meeting the minimum fees can however, apply for various types of student grants. In this sense, METU is open to students with various socio-economic backgrounds, provided that they manage to get through the highly rigorous (and costly) selection process described earlier.

There are 39 departments at METU organized under five schools; Architecture and City Planning, Economics and Administrative Sciences, Education, Engineering and Arts and Sciences. There is no medical or law school. METU was originally established as a technical university. Although social sciences were later added to it, it has nevertheless continued to have a technical character with over half the student body enrolled in one of the 13 engineering departments. Entry into METU is highly competitive. The majority of departments admit students from the top $1 \%$ of applicants taking the university placement exam. Being a well-reputed university, it attracts students from all over the country though the main crux of the student body comes from Ankara and western provinces. The proportion of students coming from east and southeast, which are relatively poorer regions of the country, is limited to less than $5 \%$ of the student body.

Women's representation in higher education across the world is increasingly approaching parity with men (Bradley, 2000). At METU female students constitute 37.4\% of the student body (Table 2) which is lower than the average (43\%) recorded for the

\footnotetext{
${ }^{5}$ For further details on METU see http://www.metu.edu.tr
} 
country at large. ${ }^{6}$ If one possible reason for the lower share of female students at METU is its engineering character, the other might be the relatively poorer performance of female students in the placement exam. We address the latter point in the ensuing sections of the paper.

The medium of instruction at METU is English so that before the students are admitted to their respective departments, they need to pass an English language test. If their background in English is found to be unsatisfactory, they enroll in the preparatory school. Progression to departments requires receiving a passing score in the language test.

\section{Methodology}

A number of indicators can be used to determine the academic achievement of an undergraduate student. In the literature, the most frequently employed measure is students' cumulative grade point average (CGPA). In this paper, we also primarily rely on CGPA to measure academic success though we do employ additional measures such as university entrance scores and progression from preparatory school to departments to capture student performance at different stages of students' academic life.

As mentioned earlier, a whole host of factors affect student achievement. The variable of prime interest for this study is the sex of the student. To see whether females have an advantage over males, we use a multivariate analysis and thereby, control all other possible predictors of CGPA.

Among individual level effects we consider student's age and his/her year of entry to university. For reasons such as repeated classes, not being able to enter university right after graduation from high school, or being on leave for a period of time, the age of the students will show variations within a given class. We might expect older students to perform better than their younger classmates for the reason they are likely to be more

\footnotetext{
${ }^{6}$ See http://www.osym.gov.tr.
} 
mature. However, if they are composed of class repeaters this might indicate either that their ability is lower than the average or that they are not as motivated as others, causing their performance to suffer.

The student's university entrance score and the type of high school attended will also be important in determining student achievement as they would be indicative of student ability and motivation. The studies that explore the determinants of university/college GPAs use mainly SAT scores, high school GPA and class rank to predict success in higher education. Among these variables SAT has long been advocated as a necessary check on potentially heterogeneous high school grading policies so as to decrease the influence of high school grade inflation (Rothstein, 2004). As mentioned earlier, the university entrance score used in this study is an amalgam of the entrance examination score, student's high school CGPA and the relative success of the student's high school in the placement exam. The use of this three-parameter scale avoids the problem of grade inflation and hence, is a better measure of student ability. Also, assuming that the student's achievement depends on his/her willingness to graduate from the department that s/he is in, we include the preference rank for his/her department as another factor. Whether or not the student was enrolled in preparatory school and the number of semesters spent there, are also controlled for to see whether or not language ability affects academic achievement.

The socio-economic background of the student may also be important in determining his/her academic achievement. Unfortunately, the data set we employ lack information relating to parental characteristics. To partly proxy for the socio-economic standing of the family, we employ student's place of permanent residence. The type of high school attended, i.e. whether it was private or not, will also be indicative of the socioeconomic standing of the family. 
In the multivariate analysis, we also employ a number of control variables reflecting departmental/school characteristics. For instance, we control for the school that the student is enrolled in for the reason that the average CGPA in a given school might be traditionally lower or higher in comparison to others. Other control variables include the gender composition of the student body and that of the faculty in the department that the student is enrolled. We conjecture that the higher is the representation of women in the form of fellow students or faculty the greater will be the academic success of female students as the former will help create a support group and a network, while the latter will act as role models. Empirical research finds mixed support for the role model hypothesis. Robst, Keil and Russo (1998) find a positive relationship between retention of female students and the percentage of science and mathematics classes taught by female faculty. No significant relationship is found for men. Canes and Rosen (1995), on the other hand, find no evidence that the gender composition of the students in a department is affected by the gender composition of the faculty. Jacobs (1996) reports mixed evidence on student satisfaction with same sex advisors and faculty. Rothstein (1995) states that the percentage of female faculty at a college had a positive, statistically significant impact on the probability that female students surveyed would attain an advanced degree.

In addition to the CGPA of students, we analyze university entrance scores, and the number of semesters spent in the preparatory school as additional indicators of academic achievement. In the analysis of university entrance scores, our interest lies in determining whether or not there are appreciable differences between male and female students in terms of educational achievement at the time they enter the university. The performance at the preparatory school, which is measured by the semesters spent there until the student achieves a passing mark in the English language test, will indicate the language ability of the student. Based on these three indicators - CGPA, university entrance scores and the number of semesters spent in the preparatory school - we hope to get an understanding 
about academic performance at different stages of student's life; at the time of college entry, before the progression to departments and during the time spent in the department itself.

One possible caveat in our analysis might be the university drop-outs. The data set we employ does include students who have failed out of their classes and face possible dismissal but not those who dropped out for personal reasons or were dismissed in earlier semesters. Dismissal occurs if a student fails to accumulate a total of 1.80 points at the end of three consecutive semesters. ${ }^{7}$ The rate of dismissal at METU is rather low, which is reported to be $0.7 \%$ of all undergraduates in the 2001-2002 academic year (METU, 2003) and $0.6 \%$ in the 2002-2003 period (METU, 2004). Given the small number of drop-outs, we do not expect them to impact on our results significantly.

\section{The data}

The data for this study come from the undergraduate student records compiled by the registrar's office of METU. We were provided with an extract of this data reflecting the academic standing of the students as of Spring 2003. Table 1 presents the descriptive statistics on the undergraduate population based on key variables. The original data included 11,560 students. We excluded international students (who constitute $4.6 \%$ of the sample) and those who have transferred from abroad for the reason that they have no university entrance score. We also dropped departments such as physical education and vocational training for the same reason that they admit students not through the university exam but via an alternative mechanism. Additional exclusions include a small number of students with missing information. With all these exclusions, the data set is reduced to 10,343 individual cases.

\footnotetext{
${ }^{7}$ The rules for dismissal have been changed starting from the 2003-2004 academic year. According to the new regulations, a student can be dismissed if $\mathrm{s} / \mathrm{he}$ fails to achieve 1.80 CGPA at the end of 14 semesters. Students who are in their final semester but who have failed at most three classes can take make-up exams.
} 
Female students constitute $37.4 \%$ of the total student body ${ }^{8}$ and are heavily represented in non-engineering departments though as mentioned earlier, METU has an engineering bias. Whether this is the result of women's choice, societal discrimination or failure to receive high enough placement scores is a question that begs an answer. As will be illustrated later in the paper, lower placement scores might partly explain the gender imbalance though considering that the teaching staff and the guidance councilors in basic and secondary schools in Turkey often carry and, consciously or unconsciously, reflect onto their students notions of gender appropriate traits and competencies and often use gender biased teaching materials (Acar et al., 1999; Helvacioğlu, 1996), the role of societal discrimination cannot be ruled out. It has also been suggested that women who expect interruptions in their work careers choose those fields that have low cost of exit and reentry (Polachek, 1981; Jacobs, 1995; Blakemore and Low, 1984) which might also explain their lower concentration in engineering departments.

The gender composition of the teaching staff also shows wide variations across schools, which is not a surprising finding given the imbalance in the gender distribution of majors (see Table 2). While women constitute $34 \%$ of the full-time teaching staff, their representation in the Faculty of Education reaches $64.2 \%$, but goes down as low as $23.4 \%$ in the Faculty of Engineering. The latter also constitutes the most competitive school with the highest average admittance score. The scoring system in the centrally managed university entrance examination changed in 1998 so that in Tables 1 and 2 we report two sets of entrance scores, one relating to students who have entered METU prior to the change in 1998 and the other for those who have entered after this date. Both sets of scores indicate that the Faculty of Engineering accepts students with relatively higher university

\footnotetext{
${ }^{8}$ Women constitute a slightly smaller proportion (about $42 \%$ ) of high school graduates taking the university exam.
} 
entrance scores. Interestingly though, the engineering students have the lowest CGPA ${ }^{9}$ of all schools, which might be indicative of its more demanding nature in relation to others.

When the CGPA of male and female students are compared, a difference in favor of the latter is observed. An opposite observation is made in terms of university entrance scores, though female applicants seem to be more successful in getting into the department of their choice which might indicate that they have lower aspirations. While male students, on average, enter their fifth choice, female students manage better, the average of their school rank being 4.4 .

A substantial portion of the students (36.9\%) come from Anatolian High Schools where the medium of instruction is in a foreign language, usually in English. Students from private schools make up a little more than one fifth of the student body, which considering the overall share of private schools in secondary education, is quite substantial. This finding goes to indicate that students at METU are a select group. Based on their high school background, a significant number of students are expected to have a fair amount of knowledge in the English language. Despite this, over $70 \%$ of the student body is found to enroll in the preparatory school before proceeding on to departments. The average number of semesters spent in the preparatory school is close to two semesters or one academic year. These results imply either that high school English does not equip students with the required language skills or that students opt to enroll in the preparatory school (by purposely not doing well in the English proficiency exam) to have a break from their studies. If the latter is the case, there is certainly a waste of resources, which needs to be avoided.

The distribution of students also shows variations by year. In comparison to males, a higher proportion of females are freshmen, whereas a smaller proportion of them are

\footnotetext{
${ }^{9}$ Courses taken from the preparatory school are excluded from CGPA calculations since they are evaluated on a pass or fail basis.
} 
seniors. The former observation stems from the fact that a smaller proportion of females attend preparatory school and when they do, they spend fewer semesters there. The latter observation, on the other hand, may stem from more timely graduation of female students. In other words, if female students are more successful in their studies, which is the subject of the next section, their presentation among seniors will be less than their overall share. As mentioned earlier, dismissal is rather unlikely which essentially means a greater concentration of students in the fourth-year.

As students mature and get used to their department, their performance improves so that higher CGPAs are recorded in upper classes. Figure 1 shows that the distribution of CGPA by year is distinctly different so that pooling students from all years might not be appropriate. Therefore, in what follows next, we analyze the academic performance of genders separately for each year. Before proceeding on to presenting our results, it is also important to emphasize that the student body at METU represents the best students in Turkey so that the conclusions drawn from this study may not be representative of the other 1.5 million students who hope to get a university degree.

\section{Academic performance by sex}

In this section of the paper, we analyze the academic performance of male and female students via three indicators; university entrance scores, the rate of progress from preparatory school to faculties and student CGPA.

\subsection{University entrance scores}

As the summary statistics indicated in Table 1, there is a gender gap in favor of male students in terms of university entrance scores. Figures $2 \mathrm{~A}$ and $2 \mathrm{~B}$ illustrate the cumulative distribution of entrance scores for male and female students for the 1999-2002 and 1996-1998 periods, respectively. In both graphs, the cumulative distribution of female 
scores lies above the distribution for males indicating the existence of a gender gap in favor of the latter. The observed difference in scores may originate from two sources; (1) Female students are less successful in the placement exam so that they enter their respective departments with lower scores, (2) Female students prefer less competitive departments that admits students with lower scores, which reduces their motivation to do well in the entrance exam or that due to their lower scores they get placed into departments with lower entrance requirements. The distribution of students across schools given in Table 1 indeed shows that female students are concentrated in schools with less competitive entrance requirements. To allow comparability across departments and to see whether female students do indeed enter their departments with lower scores, we standardize the entrance scores using the score obtained by the last student admitted to the department in question. Minimum scores show variations among departments and across time primarily due to the change in the demand for the department. Standardization, which is done by subtracting the student's score from the minimum score, accounts for interdepartmental demand differences as well as the change in the scoring scheme in 1999. ${ }^{10}$

The mean standardized university entrance scores for male and female students by schools along with the associated p-values reflecting the results of the hypothesis that there is no gender gap in entrance scores are given in Table 3. For female students the average standardized entrance score is found to be 1.94 points, whereas for male students this figure stands at 2.46 points. Although, in comparison to the crude differential the gender gap is substantially reduced, it nevertheless remain statistically significant at conventional levels $(\mathrm{p}<0.000)$. These results confirm that while a good portion of the crude gap stems

\footnotetext{
${ }^{10}$ The standardized scores may embody negative values due mainly to transfer students. If a student cannot get into the department of his/her choice but enrolls in a different program, s/he has the possibility of transferring to his/her preferred program provided s/he meets the set criteria. One of the requirements is that his/her university entrance score is not below a given cut off point, which is determined in relation to the minimum score of the department in the year that the student took the university exam.
} 
from females being placed into less competitive departments, the fact that there is a significant gender gap in standardized scores imply that they enter their respective departments with lower scores.

Analyzing the gender gap by schools shows that the gap is statistically significant to the disadvantage of women in all five schools except for the Faculty of Architecture and the Faculty of Economic and Administrative Sciences (see Table 3). The difference is especially big in the Faculty of Arts and Sciences possibly because rather diverse departments are gathered under the same school, ranging from such technical fields as physics and mathematics to departments that are more social science oriented such as sociology and history. The placement scores for male and female students by departments along with the p-values showing the statistical significance of the gender gaps are given in Appendix Table A1. Indeed, as conjectured above, the departments under the Faculty of Arts and Sciences demonstrate larger gender gaps in placement scores.

These findings are consistent with the literature on gender disparity in SAT scores in the US. However, the gap cannot be explained by differential course taking patterns between sexes since unlike the American students who can choose among courses, all Turkish high school students are required to take the same mandatory courses including math. Neither is there evidence that the university entrance exam is biased against a given sex or that male and female examinees differ in terms of socio-economic background. ${ }^{11}$ Hence, the reason for the gap must lie in the pre-collegiate experience of students.

\subsection{Preparatory school}

An imbalance is also observed in the gender composition of the preparatory school. While the proportion of male students enrolling in preparatory school at the start of their

${ }^{11}$ Even if they do, it is unlikely that the students admitted to METU will differ from each other as well. Conjecturing that the sample of male and female students will differ at the low end of the score distribution and given that METU admits only a fraction of students from top, we expect a rather homogenous student population by sex. 
college life is $74.5 \%$, the corresponding rate for female students is $68.4 \%$. The difference is statistically significant ( $\mathrm{p}$-value $<0.000$ ). There is also a small but statistically significant gap in the number of semesters male and female students spend in the preparatory school before they pass the English language test. While male students spend, on average, 1.85 semesters learning English, this figure is 1.8 semesters for females. These observations can be taken to indicate the higher language ability of female students in comparison to their male counterparts, though differences in motivation may also be a factor.

\subsection{Cumulative grade point average}

Next, we consider the academic achievement of male and female students in terms of CGPA. The summary statistics presented in Table 1 showed that female students, on average, outperform their male counterparts. To see whether this result holds when other relevant factors determining CGPA are controlled for, we run a series of OLS estimations disaggregated by year (freshman, sophomore, junior, and senior).

Running the model on a pooled sample of male and female students reveal that holding individual characteristics constant and controlling for differing departmental characteristics, females are expected to have CGPAs that are $0.12-0.13$ points higher than that of their male counterparts (see Appendix Table A2). This result holds regardless of the year of the student. Having found that the gender of the student matters in determining CGPA, we run separate regressions for male and female students to determine the factors that are instrumental in bringing about an advantage for females. The results are presented in Tables 4 and 5.

Age is an important determinant of the CGPA of male students but not of females, with the exception of first-year women. This result possibly stems from the fact that girls mature faster than boys. Younger students in a given class are found to outperform their older counterparts who are likely to be composed of class repeater or those who have 
entered the university after a number of tries. Since we are controlling for the year of entry, which has a positive effect on CGPA indicating that more recent entrants are more successful, it must be that older students are class repeaters. The results seem to be indicating that, in a given class, a larger proportion of males are composed of class repeaters which is also supported by descriptive statistics presented in Section 3.

The type of high school attended also matters. Male students graduating from Anatolian and science high schools and private language schools outperform other male students during freshman and senior years. The language skills acquired in these schools might be instrumental in helping the first-year students follow classes, while making it easier for seniors to fulfill their written assignments which intensify in the final year. However, it is interesting to note that in their second and third years, male students graduating from general public high schools that manage to send only a small number of their graduates to METU outperform others. A plausible explanation is that these are a select group of students who probably have above average skills (though not necessarily language skills) making it possible for them to enter METU. Among females, the effect of high school differences on CGPA is not so pronounced. Graduating from sciences oriented high schools help, we suspect because they equip students with better academic skills.

The (standardized) university entrance scores impact positively on CGPA though the effect is observed most strongly in the first year. While its effect lingers on to the second year for male students, it disappears for female students only to reappear in the third year, but with a much weaker effect. Even among freshmen, the impact of university entrance scores on CGPA is rather minimal. This may be due to the fact that there is not much variation in the placement scores especially when differences among departments are controlled. A student entering his/her department with an extra point as compared to the student with the lowest placement score expects to have a CGPA that is $0.02-0.04$ points higher. Holding the placement score constant, getting into a less favored department, on 
the other hand, decreases the CGPA of male and female students quite significantly. The effect is not only stronger but also persists throughout the student's college life. For instance, a freshman entering his/her $10^{\text {th }}$ choice expects to have 0.4 points lower CGPA than a fellow student entering the department as a first choice.

The preparatory school education, taking into the semesters spent there, impacts on student achievement positively. The only exception is observed for male students in the freshman year, for whom no significant effect is recorded. It is interesting to also note that additional semesters spent in the preparatory school, except for in the first year, do not seem to negatively affect student performance. The negative impact in the first year possibly stems from adjustment problems. Preparatory school education is relatively less demanding so that the longer the time spent here, the harder the transition is from the preparatory school to the department. The positive effect in upper years, on the other hand, implies that certain number of semesters in preparatory school is required to achieve competency in the English language.

The department in which the student is enrolled also matters in determining his/her CGPA. For both the male and female students, there seems to be a 'penalty' associated with being in the engineering school though as mentioned earlier, it admits students with relatively higher university entrance scores. Comparing the 'grade premium' associated with not being an engineering student across male and female students reveal that only in the freshmen year and in the Faculty of Education do the female students have a premium over their male counterparts. Male students, on the other hand, have an advantage over females in the Faculty of Architecture and Arts and Sciences in sophomore and junior years and in the Faculty of Education in their senior year.

The gender composition of the student body in the department that the student is enrolled in does not seem to impact on the success of female students. However, quite interestingly, higher female student composition works to reduce the CGPA of male 
students. Since almost the entire student body comes from co-ed schools, this effect is puzzling. A plausible explanation is that contrary to our conjecture, female students are more conservative about including their male classmates into their study groups so that where the latter constitute a minority they suffer from lack of study networks. Higher female faculty composition, on the other hand, works to increase the CGPA of both the male and female students. Although the 'role model' hypothesis would predict a positive effect for females, it is not clear why male students are also positively affected. In fact, except for the freshmen among whom the favorable effect is observed only for male students, higher female faculty ratio does not seem to particularly bring about an advantage for female students. A plausible conjecture for the equally favorable effect of women faculty on male and female students' academic performance is that women faculty members are more generous in giving out grades compared to their male counterparts.

Students from Ankara, the majority of whom would be living at home, are predicted to have higher CGPAs. So do the male students residing in dormitories on campus. Female students' academic performance seem to be less affected from being away from their families, or having to live alone possibly because they have been brought up with skills to manage on their own whereas, male students often lack such skills. Alternatively, it might be that female students are freed from their domestic obligations and therefore, perform better.

\section{Conclusion}

The study has established that despite their lower university entrance scores and under-representation in most departments, female undergraduate students outperform their male counterparts during their college years. While it is true that higher grades in the Faculty of Education and the greater concentration of female students in education departments help explain the higher CGPA for the female student population, it is also the 
case that female students outperform their male counterparts in all the other four schools considered. The multivariate analysis has further shown that, controlling for all other relevant factors, belonging to a certain school does not bring about an advantage to female students. Quite the contrary, it is the male students who enjoy a 'grade premium'. To the extent that we are controlling for student ability and other relevant individual attributes, our results seem to indicate that female students are able to make better use of their individual endowments and the opportunities offered at METU in achieving higher grades. As suggested in the literature, this would most likely to entail such factors as better class attendance, study skills, and motivation on the part of the female students.

Amidst the gender inequality in much of the public life in Turkey, higher course grades achieved by female students are encouraging. However, gender segregation by fields of study should not be overlooked. A significant portion of the gender earnings gap (as much as $45 \%$ ) among university graduates in the US is attributed to differences in majors (Solnick, 1995; Jacobs, 1996). To the extent that females are less likely to get into lucrative fields of study, this may translate into lower earnings in the future. Labor market statistics in Turkey indicate that university educated women earn less than men. The most recent statistics put this gap at little under $25 \% .^{12}$ It must also be considered that not all university educated women enter the labor market (62\% do as opposed to $78 \%$ of men). If labor market discrimination is a factor in this, then the earnings gap reported above is probably underestimated. Since METU does not keep track of the labor market performance of its graduates, it is not clear whether women alumni constitute a happy minority who find the labor market as open and satisfying as men do. It might very well be that they end up becoming part of the larger crowd of highly qualified but underemployed women.

\footnotetext{
${ }^{12}$ The figure is based on hourly earnings of men and women and is calculated by the authors using the 2002 Household Income and Consumption Expenditures Survey.
} 


\section{Acknowledgements}

This work was undertaken with the support provided by METU Scientific Project Fund (BAP-2004-04-03-02). We would like to thank Erol Taymaz for his suggestions and comments.

\section{References}

Acar, F. Güneş-Ayata, A. and Varoğlu, D. (1999) Cinsiyete Dayalı Ayırımcılık: Türkiye'de Eğitim Sektörü Örneği (Gender Discrimination: A Case Study of the Education Sector in Turkey), Ankara: KSSM

Allik, J., Must, O. and Lynn, R. (1999) Sex Differences in General Intelligence among High School Graduates: Some Results From Estonia, Personality and Individual Differences, 26, pp. 1137-1141.

Baker, D. P. and Jones, D. P. ( 1993) Creating Gender Equality: Cross-national Gender Stratification and Mathematical Performance, Sociology of Education, 66, pp. 91103.

Betts, J. R. and Morell, D. (1999) The Determinants of Undergraduate Grade Point Average: The Relative Importance of Family Background, High School Resources, and Peer Group Effects, The Journal of Human Resources, 34, pp. 268-293.

Blakemore, A. E. and Low, S. A. (1984) Sex Differences in Occupational Selection: The Choice of College Majors, Review of Economics and Statistics, 66, pp. 157-163.

Bradley, K. (2000) The Incorporation of Women into Higher Education: Paradoxical Outcomes?, Sociology of Education, 73, pp. 1-18.

Bridgeman, B. and Wendler, C. (1991) Gender Differences in Predictors of College Mathematics Performance and in College Mathematics Course Grades, Journal of Educational Psychology, 83, pp. 275-284.

Byrnes, J. P., Hong, L. and Xing, S. (1997) Gender Differences on the Math Subtest of the Scholastic Aptitude Test May Be Culture-Specific, Educational Studies in Mathematics, 34, pp. 49-66.

Canes, B. J. and Rosen, H. S. (1995) Following in Her Footsteps? Faculty Gender Composition and Women's Choices of College Majors, Industrial and Labor Relations Review, 48, pp. 486-504.

Cohn, E., Cohn, S., Hult Jr., R. E., Balch, D. C. and Bradley Jr., J. (1998) The Effects of Mathematics Background on Student Learning in Principles of Economics, Journal of Education for Business, 74, pp. 18-22.

Colom, R. and Lynn, R. (2004) Testing the Developmental Theory of Sex Differences in Intelligence on 12-18 Year Olds, Personality and Individual Differences, 36, pp. 75-82.

Dayığlu, M. and Tunalı, İ. (2003) Falling Behind While Catching Up: Changes in the Female-Male Wage Differential in Urban Turkey, 1988 to 1994, paper presented at the 2003 Annual Meeting of the Population Association of America.

Ertürk, Y. and Dayığlu, M. (forthcoming) Gender, Education and Child Labor in Turkey, Geneva: ILO.

Feingold, A. (1988) Cognitive Gender Differences Are Disappearing, American Psychologist, 43, 95-103.

Flynn, J. R. (1998) Israeli Military IQ Tests: Gender Differences Small; IQ gains Large, Journal of Biosocial Sciences, 30, pp. 541-553.

Helvacioğlu, F. (1996) Ders Kitaplarında Cinsiyetçilik (Gender Bias in School Textbooks), Ankara: Kaynak Publishing. 
Hyde, J. S. and Kling, K. C. (2001) Women, Motivation and Achievement, Psychology of Women Quarterly, 25, 364-378.

Jacobs, J. A. (1995) Gender and Academic Specialties: Trends among Recipients of College Degrees in the 1980s, Sociology of Education, 68, pp. 81-98.

Jacobs, J. A. (1996) Gender Inequality and Higher Education, Annual Review of Sociology, 22, pp. 153-185.

Kim, M. M., Rhoades, G. and Woodard Jr., D. B. (2003) Sponsored Research versus Graduating Students? Intervening Variables and Unanticipated Findings in Public Research Universities, Research in Higher Education, 44, pp. 51-81.

Kimball, M. M. (1989) A New Perspective on Women's Math Achievement, Psychological Bulletin, 105, pp. 198-214.

Lao, R. C. (1980) Differential Factors Affecting Male and Female Academic Performance in High School, The Journal of Psychology, 104, pp.119-127.

Leonard, D. K. and Jiang, J. (1999) Gender Bias and the College Predictors of the SATs: A Cry of Despair, Research in Higher Education, 40, pp. 375-407.

Lynn, R. (1998a) Sex Differences in Intelligence: A Rejoinder to Mackintosh, Journal of Biosocial Sciences, 30, pp. 529-532.

Lynn, R. (1998b) Sex Differences in Intelligence: Some Comments on Mackintosh and Flynn, Journal of Biosocial Sciences, 30, pp. 555-559.

Lynn, R. (1999) Sex Differences in Intelligence and Brain Size: A Developmental Theory, Intelligence, 27, pp. 1-12.

Lynn, R. and Tse-Chan, P. W. (2003) Sex Differences on the Progressive Matrices: Some Data From Hong Kong, Journal of Biosocial Sciences, 35, pp. 145-150.

Mackintosh, N. J. (1998) Reply to Lynn, Journal of Biosocial Sciences, 30, pp. 533-539.

Ministry of National Education (MNE) (2004) Statistics on National Education 20022003, http://www.meb.gov.tr

Middle East Technical University (2003). 2002 Faaliyet Raporu (Activities Report), Ankara: METU.

Middle East Technical University (2004). 2003 Faaliyet Raporu (Activities Report), Ankara: METU.

Morris, V. C. (1959) Male, Female, and the Higher Learning: The Educational Significance of Differences between the Sexes, Journal of Higher Education, 30, pp. 67-72.

OECD (2001) Education at a Glance: OECD Indicators, Paris: OECD Publicatons.

Polachek, S. W. (1981) Occupational Self-Selection: A Human Capital Approach to Sex Differences in Occupational Structure, The Review of Economics and Statistics, 63, pp. 60-69.

Robst, J., Keil, J. and Russo, D. (1998) The Effect of Gender Composition of Faculty on Student Retention, Economics of Education Review, 17, pp. 429-439.

Rothstein, D. S. (1995) Do Female Faculty Influence Female Students' Educational and Labor Market Attainments?, Industrial and Labor Relations Review, 48, pp. 515530.

Rothstein, J. M. (2004) College Performance Predictions and the SAT, Journal of Econometrics, 121, 297-317.

Solnick, S. J. (1995) Changes in Women's Majors from Entrance to Graduation at Women's and Coeducational Colleges, Industrial and Labor Relations Review, 48, pp. 505-514.

Stage, F. K. and Kloosterman, P. (1995) Gender, Beliefs, and Achievement in Remedial College-Level Mathematics, Journal of Higher Education, 66, pp. 294-311.

State Institute of Statistics (SIS) (2003). Census of Population 2000, Ankara: SIS.

Student Selection and Placement Center (SSPC) (2004) http://www.osym.gov.tr. 
T.C. Yükseköğretim Kurulu (2003) Türk Yükseköğretiminin Bugünkü Durumu March 2003 (http://www.yok.gov.tr/egitim/raporlar/Mart2003).

Tansel, A. (2002) Determinants of School Attainment of Boys and Girls in Turkey: Individual, Household and Community Factors, Economics of Education Review, 21, pp. $455-470$.

Wainer, H. and Steinberg, L. S. (1992) Sex Differences in Performance on the Mathematics Section of the Scholastic Aptitude Test: A Bidirectional Validity Study, Harvard Educational Review, 62, pp. 323-336.

Wilberg, S. and Lynn, R. (1999) Sex Differences in Historical Knowledge and School Grades: A 26 Nation Study, Personality and Individual Differences, 27, pp. 12211229.

Young, J. W. and Fisler, J. L. (2000) Sex Differences on the SAT: An Analysis of Demographic and Educational Variables, Research in Higher Education, 41, pp. 401-416.

Younger, M., Warrington, M. and Williams, J. (1999) The Gender Gap and Classroom Interactions: Reality and Rhetoric? British Journal of Sociology of Education, 20, pp. 325-341. 
Table 1 Descriptive statistics on key variables

\begin{tabular}{|c|c|c|c|}
\hline & All & Male & Female \\
\hline \multirow[t]{2}{*}{ Age } & 21.43 & 21.57 & 21.18 \\
\hline & $(1.52)$ & $(1.58)$ & (1.39) \\
\hline University entrance score: & 210.60 & 213.85 & 205.68 \\
\hline $1999-2002$ & $(11.11)$ & $(9.50)$ & (11.55) \\
\hline University entrance score: & 527.95 & 533.27 & 514.43 \\
\hline $1996-1998$ & $(31.23)$ & $(30.71)$ & $(28.35)$ \\
\hline \multirow[t]{2}{*}{ CGPA } & 2.56 & 2.48 & 2.70 \\
\hline & $(0.65)$ & $(0.67)$ & $(0.61)$ \\
\hline \multicolumn{4}{|l|}{ Year at university } \\
\hline First year & 26.54 & 25.50 & 28.29 \\
\hline Second year & 25.33 & 25.17 & 25.60 \\
\hline Third year & 23.11 & 22.41 & 24.28 \\
\hline Fourth year & 25.02 & 26.92 & 21.84 \\
\hline \multicolumn{4}{|l|}{ School } \\
\hline Architecture & 5.64 & 3.84 & 8.64 \\
\hline Arts and Sciences & 11.29 & 7.38 & 17.86 \\
\hline Economics and Administrative Sc. & 16.36 & 12.53 & 22.77 \\
\hline Education & 15.15 & 11.31 & 21.58 \\
\hline Engineering & 51.56 & 64.93 & 28.14 \\
\hline \multicolumn{4}{|l|}{ High School Type } \\
\hline Anatolian (public foreign language) & 36.95 & 35.11 & 40.03 \\
\hline Sciences & 9.33 & 10.97 & 6.57 \\
\hline Regular high school & 19.90 & 22.64 & 15.30 \\
\hline Private Sciences & 4.07 & 5.09 & 2.36 \\
\hline Private regular & 1.55 & 1.85 & 1.04 \\
\hline Private language school & 17.82 & 16.18 & 20.57 \\
\hline Other & 10.38 & 8.16 & 14.13 \\
\hline \multirow[t]{2}{*}{ Preference rank for department } & 4.82 & 5.06 & 4.42 \\
\hline & $(3.37)$ & $(3.46)$ & $(3.17)$ \\
\hline Prep school: Yes & 72.21 & 74.74 & 68.43 \\
\hline \multirow{2}{*}{ Semesters in prep. school } & 1.83 & 1.85 & 1.80 \\
\hline & $(0.64)$ & $(0.65)$ & $(0.63)$ \\
\hline Resides in dormitory & 40.07 & 35.51 & 47.70 \\
\hline Permanent residence in Ankara & 34.21 & 34.26 & 34.11 \\
\hline No. of observations & 10,343 & 6,479 & 3,864 \\
\hline
\end{tabular}

Note: For continuous variables standard deviations are given in parenthesis. The discrete variables are given in percentage terms. 
Table 2 Summary statistics on faculties

\begin{tabular}{lcccccc} 
Schools & $\begin{array}{c}\text { Prop. of } \\
\text { female } \\
\text { students }\end{array}$ & $\begin{array}{c}\text { Prop. of } \\
\text { female } \\
\text { faculty }\end{array}$ & $\begin{array}{c}\text { University } \\
\text { entrance } \\
\text { score: } \\
1996-1998\end{array}$ & $\begin{array}{c}\text { University } \\
\text { entrance } \\
\text { score: } \\
1999-2002\end{array}$ & CGPA & N \\
\hline Architecture & 57.29 & 46.62 & 539.74 & 214.54 & 2.56 & 583 \\
Arts and Sciences & 52.01 & \multirow{2}{*}{36.12} & $\begin{array}{c}(20.82) \\
(503.06\end{array}$ & $\begin{array}{c}(5.43) \\
(0.46)\end{array}$ & \\
& & & $(27.56)$ & $(11.27)$ & $(0.70)$ & \\
Economic and & 53.22 & 40.57 & 509.00 & 201.35 & 2.73 & 1,567 \\
Administrative Sc. & & & $(12.22)$ & $(4.36)$ & $(0.63)$ & \\
Education & 59.08 & \multirow{2}{*}{64.23} & 503.69 & 200.10 & 2.61 & 1,168 \\
& & & $(16.24)$ & $(11.44)$ & $(0.62)$ & \\
Engineering & 21.11 & 23.37 & 544.36 & 217.57 & 2.51 & 5,333 \\
& & & $(27.66)$ & $(6.62)$ & $(0.66)$ & \\
All & \multirow{2}{*}{37.36} & \multirow{2}{*}{33.99} & 528.95 & 210.60 & 2.56 & 10,343 \\
& & & $(31.23)$ & $(11.11)$ & $(0.65)$ &
\end{tabular}

Note: Standard deviations are given in parentheses.

Table 3 Standardized university entrance scores for male and female students

Standardized entrance scores of

\begin{tabular}{lccccc} 
Schools & $\begin{array}{c}\text { male } \\
\text { students }\end{array}$ & $\begin{array}{c}\text { pemale } \\
\text { students }\end{array}$ & $\begin{array}{c}\text { p-value for } \\
\text { the difference } \\
\text { in average } \\
\text { entrance } \\
\text { scores }\end{array}$ & Male & Female \\
\hline Architecture & 2.567 & 2.271 & 0.297 & 249 & 334 \\
Arts and & $(0.214)$ & $(0.185)$ & & & \\
Sciences & 4.241 & 2.391 & 0.000 & 812 & 880 \\
Economic and & $(0.216)$ & $(0.134)$ & & & \\
Admin. Sciences & 1.611 & 1.505 & 0.325 & 733 & 834 \\
Education & $(0.082)$ & $(0.070)$ & & & \\
Engineering & 2.806 & 1.947 & 0.001 & 478 & 690 \\
All & $(0.237)$ & $(0.143)$ & & & \\
& 2.222 & 1.807 & 0.000 & 4,207 & 1,126 \\
& $(0.053)$ & $(0.085)$ & & & \\
& 2.462 & 1.940 & 0.000 & 6,479 & 3,864 \\
& $(0.050)$ & $(0.052)$ & & &
\end{tabular}

Note: Standard errors are given in parentheses. 
Table 4 OLS estimates for the determinants of CGPA for male students by year

\begin{tabular}{|c|c|c|c|c|}
\hline & $\begin{array}{l}\text { First-year } \\
\text { students }\end{array}$ & $\begin{array}{l}\text { Second-year } \\
\text { students }\end{array}$ & $\begin{array}{l}\text { Third-year } \\
\text { students }\end{array}$ & $\begin{array}{c}\text { Fourth-year } \\
\text { students }\end{array}$ \\
\hline Age & $\begin{array}{c}-0.068^{* * *} \\
{[0.025]}\end{array}$ & $\begin{array}{c}-0.073^{\star * *} \\
{[0.017]}\end{array}$ & $\begin{array}{c}-0.038^{\star *} \\
{[0.018]}\end{array}$ & $\begin{array}{c}-0.048^{\star \star *} \\
{[0.014]}\end{array}$ \\
\hline \multicolumn{5}{|l|}{ High School Type (ref. Other) } \\
\hline Anatolian & $\begin{array}{c}0.287^{\star * *} \\
{[0.102]}\end{array}$ & $\begin{array}{l}-0.106 \\
{[0.076]}\end{array}$ & $\begin{array}{l}-0.137^{*} \\
{[0.075]}\end{array}$ & $\begin{array}{l}0.115^{\star *} \\
{[0.050]}\end{array}$ \\
\hline Sciences & $\begin{array}{l}0.248^{\star \star} \\
{[0.112]}\end{array}$ & $\begin{array}{l}-0.108 \\
{[0.084]}\end{array}$ & $\begin{array}{l}-0.037 \\
{[0.085]}\end{array}$ & $\begin{array}{l}0.162^{\star *} \\
{[0.065]}\end{array}$ \\
\hline Regular high school & $\begin{array}{l}-0.022 \\
{[0.110]}\end{array}$ & $\begin{array}{c}-0.207^{* * *} \\
{[0.076]}\end{array}$ & $\begin{array}{c}-0.259^{* * *} \\
{[0.073]}\end{array}$ & $\begin{array}{c}-0.017 \\
{[0.047]}\end{array}$ \\
\hline Private sciences & $\begin{array}{l}-0.088 \\
{[0.135]}\end{array}$ & $\begin{array}{c}-0.268^{\star \star \star *} \\
{[0.094]}\end{array}$ & $\begin{array}{l}-0.153^{*} \\
{[0.093]}\end{array}$ & $\begin{array}{l}-0.001 \\
{[0.069]}\end{array}$ \\
\hline Private regular & $\begin{array}{l}-0.083 \\
{[0.151]}\end{array}$ & $\begin{array}{c}-0.379^{* \star \star} \\
{[0.114]}\end{array}$ & $\begin{array}{c}-0.256^{\star *} \\
{[0.128]}\end{array}$ & $\begin{array}{c}0.085 \\
{[0.094]}\end{array}$ \\
\hline Private language school & $\begin{array}{l}0.216^{\star \star} \\
{[0.105]}\end{array}$ & $\begin{array}{l}-0.136^{\star} \\
{[0.077]}\end{array}$ & $\begin{array}{l}-0.158^{\star *} \\
{[0.080]}\end{array}$ & $\begin{array}{l}0.133^{\star \star} \\
{[0.060]}\end{array}$ \\
\hline Std. university entrance score & $\begin{array}{l}0.038^{* * *} \\
{[0.009]}\end{array}$ & $\begin{array}{l}0.019^{\star * \star} \\
{[0.006]}\end{array}$ & $\begin{array}{c}0.001 \\
{[0.004]}\end{array}$ & $\begin{array}{c}0.003 \\
{[0.002]}\end{array}$ \\
\hline Preference for department & $\begin{array}{c}-0.044^{\star \star \star} \\
{[0.007]}\end{array}$ & $\begin{array}{l}-0.018^{\star * \star} \\
{[0.004]}\end{array}$ & $\begin{array}{c}-0.022^{\star * \star} \\
{[0.004]}\end{array}$ & $\begin{array}{c}-0.024^{* * *} \\
{[0.003]}\end{array}$ \\
\hline Year of entry to university & $\begin{array}{c}0.101 \\
{[0.065]}\end{array}$ & $\begin{array}{l}0.293^{\star * *} \\
{[0.033]}\end{array}$ & $\begin{array}{c}0.278^{\star \star \star} \\
{[0.030]}\end{array}$ & $\begin{array}{c}0.248^{* * *} \\
{[0.020]}\end{array}$ \\
\hline Prep school: Yes & $\begin{array}{l}0.209^{\star \star} \\
{[0.082]}\end{array}$ & $\begin{array}{l}-0.148^{\star *} \\
{[0.064]}\end{array}$ & $\begin{array}{l}0.164^{\star \star *} \\
{[0.058]}\end{array}$ & $\begin{array}{l}0.291^{* * *} \\
{[0.047]}\end{array}$ \\
\hline Semesters in prep school & $\begin{array}{l}-0.250^{* * *} \\
{[0.053]}\end{array}$ & $\begin{array}{l}0.198^{* * *} \\
{[0.030]}\end{array}$ & $\begin{array}{l}0.073^{* * *} \\
{[0.027]}\end{array}$ & $\begin{array}{l}-0.021 \\
{[0.019]}\end{array}$ \\
\hline Schools (ref. Engineering) & & & & \\
\hline Architecture & $\begin{array}{c}0.437^{\star * *} \\
{[0.114]}\end{array}$ & $\begin{array}{l}0.203^{\star * *} \\
{[0.064]}\end{array}$ & $\begin{array}{c}0.109 \\
{[0.073]}\end{array}$ & $\begin{array}{l}-0.013 \\
{[0.058]}\end{array}$ \\
\hline Arts and Sciences & $\begin{array}{c}0.05 \\
{[0.076]}\end{array}$ & $\begin{array}{l}0.279^{\star \star \star} \\
{[0.052]}\end{array}$ & $\begin{array}{c}0.338^{\star \star *} \\
{[0.054]}\end{array}$ & $\begin{array}{c}0.053 \\
{[0.044]}\end{array}$ \\
\hline Economic and Administrative Sciences & $\begin{array}{l}0.343^{\star * *} \\
{[0.087]}\end{array}$ & $\begin{array}{l}0.294^{\star \star *} \\
{[0.056]}\end{array}$ & $\begin{array}{l}0.347^{* * *} \\
{[0.056]}\end{array}$ & $\begin{array}{c}0.045 \\
{[0.050]}\end{array}$ \\
\hline Education & $\begin{array}{c}0.093 \\
{[0.108]}\end{array}$ & $\begin{array}{l}-0.089 \\
{[0.075]}\end{array}$ & $\begin{array}{l}0.181^{\star *} \\
{[0.079]}\end{array}$ & $\begin{array}{l}0.219^{* * *} \\
{[0.057]}\end{array}$ \\
\hline Prop. of female students in department & $\begin{array}{c}-1.171^{\star \star \star} \\
{[0.240]}\end{array}$ & $\begin{array}{c}-1.065^{\star \star \star} \\
{[0.169]}\end{array}$ & $\begin{array}{c}-0.900^{\star * \star} \\
{[0.170]}\end{array}$ & $\begin{array}{l}-0.126 \\
{[0.148]}\end{array}$ \\
\hline Prop. of female faculty in department & $\begin{array}{l}0.803^{* * *} \\
{[0.198]}\end{array}$ & $\begin{array}{l}0.651^{* * *} \\
{[0.135]}\end{array}$ & $\begin{array}{l}0.662^{* * *} \\
{[0.144]}\end{array}$ & $\begin{array}{l}0.213^{*} \\
{[0.125]}\end{array}$ \\
\hline Resides in dormitory & $\begin{array}{l}0.211^{\star * *} \\
{[0.050]}\end{array}$ & $\begin{array}{l}0.083^{\star \star \star} \\
{[0.032]}\end{array}$ & $\begin{array}{l}0.090^{* * *} \\
{[0.031]}\end{array}$ & $\begin{array}{c}0.012 \\
{[0.028]}\end{array}$ \\
\hline Ankara & $\begin{array}{l}0.201^{\star *} \\
{[0.081]}\end{array}$ & $\begin{array}{c}0.075 \\
{[0.053]}\end{array}$ & $\begin{array}{l}0.244^{\star * *} \\
{[0.048]}\end{array}$ & $\begin{array}{l}0.111^{* * *} \\
{[0.041]}\end{array}$ \\
\hline Constant & $\begin{array}{c}2.823^{\star \star \star} \\
{[0.795]}\end{array}$ & $\begin{array}{c}2.537^{\star \star \star} \\
{[0.485]}\end{array}$ & $\begin{array}{c}2.264^{\star * *} \\
{[0.501]}\end{array}$ & $\begin{array}{c}3.007^{* * *} \\
{[0.390]}\end{array}$ \\
\hline No. of observations & 1652 & 1631 & 1452 & 1744 \\
\hline $\mathrm{R}$-squared & 0.217 & 0.218 & 0.227 & 0.254 \\
\hline
\end{tabular}

Notes: ***significant at $1 \%, * *$ significant at $5 \%, *$ significant at $10 \%$. Huber-White standard errors reported. Regions indicating permanent place of residence are omitted for brevity. 
Table 5 OLS estimates for the determinants of CGPA for female students by year

\begin{tabular}{|c|c|c|c|c|}
\hline & $\begin{array}{l}\text { First-year } \\
\text { students }\end{array}$ & $\begin{array}{l}\text { Second-year } \\
\text { students }\end{array}$ & $\begin{array}{l}\text { Third-year } \\
\text { students }\end{array}$ & $\begin{array}{c}\text { Fourth-year } \\
\text { students }\end{array}$ \\
\hline \multirow[t]{2}{*}{ Age } & $-0.057^{* *}$ & -0.027 & -0.022 & -0.012 \\
\hline & {$[0.027]$} & {$[0.026]$} & {$[0.026]$} & [0.022] \\
\hline \multicolumn{5}{|l|}{ High School Type (ref. Other) } \\
\hline \multirow[t]{2}{*}{ Anatolian } & 0.121 & 0.082 & 0.066 & 0.059 \\
\hline & {$[0.090]$} & {$[0.082]$} & {$[0.071]$} & {$[0.072]$} \\
\hline \multirow[t]{2}{*}{ Sciences } & $0.395^{\star * *}$ & $0.235^{\star \star}$ & $0.158^{*}$ & $0.243^{\star *}$ \\
\hline & {$[0.119]$} & {$[0.102]$} & {$[0.091]$} & {$[0.095]$} \\
\hline \multirow[t]{2}{*}{ Regular high school } & 0.003 & 0.038 & -0.019 & 0.03 \\
\hline & {$[0.137]$} & {$[0.088]$} & {$[0.075]$} & {$[0.070]$} \\
\hline \multirow[t]{2}{*}{ Private sciences } & $0.455^{\star \star}$ & 0.055 & 0.19 & 0.035 \\
\hline & {$[0.182]$} & {$[0.134]$} & {$[0.125]$} & {$[0.160]$} \\
\hline \multirow[t]{2}{*}{ Private regular } & -0.02 & $0.297^{\star *}$ & -0.11 & $-0.326^{*}$ \\
\hline & [0.162] & {$[0.140]$} & {$[0.166]$} & {$[0.176]$} \\
\hline \multirow[t]{2}{*}{ Private language school } & 0.115 & 0.118 & $0.131^{*}$ & 0.108 \\
\hline & {$[0.093]$} & [0.083] & {$[0.073]$} & {$[0.084]$} \\
\hline \multirow[t]{2}{*}{ Std. university entrance score } & $0.028^{\star * *}$ & 0.007 & $0.012^{*}$ & 0.001 \\
\hline & {$[0.010]$} & {$[0.008]$} & {$[0.006]$} & {$[0.003]$} \\
\hline \multirow[t]{2}{*}{ Preference for department } & $-0.033^{\star \star *}$ & $-0.026^{\star \star *}$ & $-0.014^{\star *}$ & $-0.012^{\star *}$ \\
\hline & {$[0.007]$} & {$[0.006]$} & {$[0.005]$} & {$[0.005]$} \\
\hline \multirow[t]{2}{*}{ Year of entry to university } & 0.062 & $0.380^{* * *}$ & $0.339^{* * *}$ & $0.343^{* * *}$ \\
\hline & {$[0.088]$} & {$[0.079]$} & {$[0.067]$} & {$[0.038]$} \\
\hline \multirow[t]{2}{*}{ Prep school: Yes } & $0.615^{\star \star *}$ & -0.208 & $0.186^{\star}$ & $0.359^{* \star *}$ \\
\hline & {$[0.107]$} & {$[0.147]$} & {$[0.101]$} & {$[0.058]$} \\
\hline \multirow[t]{2}{*}{ Semesters in prep school } & $-0.534^{\star \star *}$ & $0.273^{\star \star \star}$ & 0.06 & -0.019 \\
\hline & {$[0.058]$} & {$[0.072]$} & {$[0.060]$} & {$[0.025]$} \\
\hline \multicolumn{5}{|l|}{ Schools (ref. Engineering) } \\
\hline \multirow[t]{2}{*}{ Architecture } & 0.135 & -0.085 & -0.055 & $-0.115^{\star}$ \\
\hline & {$[0.083]$} & {$[0.065]$} & {$[0.068]$} & {$[0.063]$} \\
\hline \multirow[t]{2}{*}{ Arts and Sciences } & $0.201^{* * *}$ & 0.08 & $0.148^{\star *}$ & 0.067 \\
\hline & {$[0.076]$} & {$[0.063]$} & {$[0.064]$} & [0.067] \\
\hline \multirow[t]{2}{*}{ Economic and Administrative Sciences } & $0.365^{\star \star *}$ & $0.181^{* \star *}$ & $0.283^{\star \star *}$ & 0.064 \\
\hline & {$[0.077]$} & {$[0.062]$} & {$[0.060]$} & [0.062] \\
\hline \multirow[t]{2}{*}{ Education } & $0.404^{* * *}$ & 0.045 & 0.137 & 0.083 \\
\hline & {$[0.102]$} & {$[0.094]$} & {$[0.086]$} & {$[0.073]$} \\
\hline \multirow[t]{2}{*}{ Prop. of female students in department } & -0.033 & 0.009 & 0.047 & -0.1 \\
\hline & {$[0.231]$} & {$[0.172]$} & {$[0.176]$} & [0.200] \\
\hline \multirow[t]{2}{*}{ Prop. of female faculty in department } & 0.159 & $0.436^{\star * *}$ & $0.333^{* *}$ & $0.449^{\star * *}$ \\
\hline & {$[0.220]$} & {$[0.163]$} & {$[0.165]$} & {$[0.179]$} \\
\hline \multirow[t]{2}{*}{ Resides in dormitory } & 0.011 & -0.046 & -0.008 & 0.043 \\
\hline & {$[0.065]$} & {$[0.044]$} & {$[0.041]$} & {$[0.038]$} \\
\hline \multirow[t]{2}{*}{ Ankara } & 0.076 & 0.056 & $0.148^{\star *}$ & $0.188^{\star \star \star}$ \\
\hline & {$[0.088]$} & {$[0.071]$} & {$[0.063]$} & {$[0.065]$} \\
\hline \multirow[t]{2}{*}{ Constant } & $3.165^{\star \star \star}$ & 0.511 & $1.284^{*}$ & $1.546^{\star \star \star}$ \\
\hline & {$[0.947]$} & {$[0.845]$} & {$[0.736]$} & {$[0.596]$} \\
\hline No. of observations & 1093 & 989 & 938 & 844 \\
\hline R-squared & 0.187 & 0.143 & 0.167 & 0.217 \\
\hline
\end{tabular}

Notes: ***significant at $1 \%, * *$ significant at $5 \%, *$ significant at $10 \%$. Huber-White standard errors reported. Regions indicating permanent place of residence are omitted for brevity. 
Table A1 Standardized entrance scores for male and female students by departments

\begin{tabular}{|c|c|c|c|c|c|}
\hline & Standardized & ance scores of & & Number & students \\
\hline Departments & $\begin{array}{c}\text { male } \\
\text { students }\end{array}$ & $\begin{array}{c}\text { female } \\
\text { students }\end{array}$ & $\begin{array}{l}\text { p-value for } \\
\text { the difference } \\
\text { in average } \\
\text { entrance } \\
\text { scores }\end{array}$ & Male & Female \\
\hline Architecture & & & & & \\
\hline Architecture & $3.11(0.34)$ & $2.31(0.28)$ & 0.075 & 109 & 158 \\
\hline City and Regional Planning & $2.47(0.41)$ & $2.88(0.34)$ & 0.433 & 81 & 105 \\
\hline Industrial Design & $1.69(0.24)$ & $1.29(0.30)$ & 0.308 & 59 & 71 \\
\hline Arts and Sciences & & & & & \\
\hline Biology & $5.46(1.08)$ & $3.17(0.62)$ & 0.049 & 42 & 73 \\
\hline Molecular Bio. and Genetics & $2.24(0.79)$ & $1.52(0.41)$ & 0.407 & 40 & 46 \\
\hline Chemistry & $4.30(0.56)$ & $2.65(0.35)$ & 0.012 & 110 & 115 \\
\hline Mathematics & $2.84(0.29)$ & $1.62(0.30)$ & 0.005 & 199 & 125 \\
\hline History & $1.63(0.39)$ & $2.21(0.48)$ & 0.357 & 49 & 58 \\
\hline Philosophy & $5.11(0.14)$ & $2.78(0.43)$ & 0.032 & 40 & 59 \\
\hline Physics & $6.99(0.56)$ & $3.74(0.63)$ & 0.003 & 189 & 57 \\
\hline Psychology & $2.28(1.04)$ & $2.45(0.29)$ & 0.836 & 23 & 136 \\
\hline Sociology & $6.74(1.68)$ & $2.55(0.46)$ & 0.001 & 32 & 130 \\
\hline Statistics & $2.43(0.41)$ & $1.56(0.24)$ & 0.071 & 88 & 81 \\
\hline Econ. and Admin. Sciences & & & & & \\
\hline Business Administration & $1.33(0.13)$ & $1.62(0.16)$ & 0.140 & 229 & 196 \\
\hline Economics & $1.38(0.13)$ & $1.17(0.13)$ & 0.251 & 217 & 230 \\
\hline International Relations & $1.78(0.19)$ & $1.78(0.19)$ & 0.981 & 97 & 152 \\
\hline Public Administration & $2.13(0.21)$ & $1.55(0.10)$ & 0.007 & 190 & 256 \\
\hline Education & & & & & \\
\hline Chemistry Education & $3.16(0.82)$ & $2.90(0.64)$ & 0.801 & 57 & 59 \\
\hline Computer \& Teaching Tech. & $4.74(0.46)$ & $4.56(0.71)$ & 0.844 & 141 & 49 \\
\hline Foreign Languages & $0.73(0.35)$ & $0.99(0.17)$ & 0.466 & 109 & 320 \\
\hline Math Education & $1.84(0.30)$ & $2.74(0.36)$ & 0.085 & 43 & 73 \\
\hline Physics Education & $3.38(0.79)$ & $2.49(0.88)$ & 0.468 & 77 & 46 \\
\hline Sciences Education & $1.39(0.17)$ & $1.25(0.22)$ & 0.633 & 50 & 77 \\
\hline Engineering & & & & & \\
\hline Aerospace Engineering & $1.57(0.19)$ & $2.11(0.86)$ & 0.351 & 169 & 42 \\
\hline Chemical Engineering & $2.52(0.24)$ & $1.94(0.25)$ & 0.373 & 242 & 171 \\
\hline Civil Engineering & $2.70(0.13)$ & $2.18(0.34)$ & 0.192 & 756 & 88 \\
\hline Computer Engineering & $1.25(0.13)$ & $1.07(0.14)$ & 0.483 & 355 & 104 \\
\hline Electrical Engineering & $1.63(0.09)$ & $1.17(0.16)$ & 0.058 & 758 & 105 \\
\hline Environmental Engineering & $2.53(0.36)$ & $2.15(0.30)$ & 0.426 & 114 & 102 \\
\hline Food Engineering & $1.56(0.22)$ & $1.73(0.20)$ & 0.556 & 121 & 118 \\
\hline Geological Engineering & $3.98(0.40)$ & $2.35(0.31)$ & 0.012 & 123 & 55 \\
\hline Industrial Engineering & $1.61(0.13)$ & $1.67(0.22)$ & 0.811 & 319 & 131 \\
\hline Mechanical Engineering & $2.26(0.13)$ & $1.81(0.22)$ & 0.269 & 769 & 84 \\
\hline Metallurgical Engineering & $3.29(0.35)$ & $2.00(0.32)$ & 0.056 & 233 & 66 \\
\hline Mine Engineering & $4.34(0.39)$ & $2.83(0.88)$ & 0.079 & 114 & 35 \\
\hline Petroleum Engineering & $2.53(0.33)$ & $1.43(0.69)$ & 0.186 & 134 & 25 \\
\hline
\end{tabular}

Note 1: Standard errors are given in parentheses.

Note 2: Average entrance scores for the Department of Early Childhood Education under the School of Education are not reported since there is only one male student in the department. 
Table A2 OLS estimates for the determinants of CGPA by year

\begin{tabular}{|c|c|c|c|c|}
\hline ( & $\begin{array}{l}\text { First-year } \\
\text { students }\end{array}$ & $\begin{array}{l}\text { Second-year } \\
\text { students }\end{array}$ & $\begin{array}{l}\text { Third-year } \\
\text { students }\end{array}$ & $\begin{array}{c}\text { Fourth-year } \\
\text { students }\end{array}$ \\
\hline Age & $-0.066^{* * *}$ & $-0.063^{* * *}$ & $-0.034^{* *}$ & $-0.038^{* \star *}$ \\
\hline & {$[0.020]$} & {$[0.014]$} & {$[0.015]$} & [0.012] \\
\hline Female & $0.119^{* * *}$ & $0.134^{* \star *}$ & $0.128^{* * *}$ & $0.132^{\star \star *}$ \\
\hline & {$[0.033]$} & {$[0.024]$} & {$[0.025]$} & {$[0.021]$} \\
\hline High School Type (ref. Other) & & & & \\
\hline Anatolian & $0.268^{* * *}$ & 0.012 & -0.027 & $0.106^{\star \star *}$ \\
\hline & {$[0.068]$} & {$[0.057]$} & {$[0.052]$} & {$[0.040]$} \\
\hline Sciences & $0.342^{* * *}$ & 0.06 & 0.066 & $0.193^{* * *}$ \\
\hline & {$[0.080]$} & {$[0.065]$} & {$[0.062]$} & {$[0.054]$} \\
\hline Regular high school & 0.014 & -0.07 & $-0.137^{\star \star \star}$ & 0.005 \\
\hline & {$[0.081]$} & {$[0.058]$} & [0.052] & [0.038] \\
\hline Private sciences & 0.077 & -0.105 & -0.016 & 0.011 \\
\hline & {$[0.107]$} & {$[0.076]$} & {$[0.071]$} & [0.062] \\
\hline Private regular & 0.029 & -0.109 & $-0.173^{*}$ & 0.031 \\
\hline & [0.108] & {$[0.095]$} & {$[0.100]$} & {$[0.085]$} \\
\hline Private language school & $0.224^{* * *}$ & 0.009 & -0.012 & $0.135^{\star * *}$ \\
\hline & {$[0.070]$} & {$[0.058]$} & {$[0.055]$} & {$[0.048]$} \\
\hline University entrance score & $0.033^{* * *}$ & $0.015^{* * *}$ & 0.004 & 0.002 \\
\hline & {$[0.007]$} & {$[0.005]$} & {$[0.003]$} & {$[0.002]$} \\
\hline Preference rank for department & $-0.043^{* * *}$ & $-0.022^{* * *}$ & $-0.021^{\star \star \star}$ & $-0.021^{\star \star \star}$ \\
\hline & {$[0.005]$} & {$[0.004]$} & [0.003] & [0.003] \\
\hline Year of entry to university & $0.095^{\star}$ & $0.313^{* * *}$ & $0.304^{\star * *}$ & $0.268^{* * *}$ \\
\hline & {$[0.052]$} & {$[0.031]$} & {$[0.026]$} & {$[0.018]$} \\
\hline Prep school: Yes & $0.362^{* * *}$ & $-0.155^{\star \star \star}$ & $0.169^{* * *}$ & $0.314^{\star * *}$ \\
\hline & {$[0.067]$} & {$[0.057]$} & {$[0.051]$} & {$[0.037]$} \\
\hline Semesters in prep school & $-0.343^{* * *}$ & $0.219^{* * *}$ & $0.074^{* * *}$ & -0.023 \\
\hline & {$[0.041]$} & {$[0.029]$} & {$[0.026]$} & {$[0.015]$} \\
\hline Schools (ref. Engineering) & & & & \\
\hline Architecture & $0.205^{* * *}$ & 0.022 & 0.025 & -0.061 \\
\hline & {$[0.066]$} & {$[0.045]$} & {$[0.048]$} & {$[0.041]$} \\
\hline Arts and Sciences & $0.090^{*}$ & $0.176^{* \star *}$ & $0.259^{* \star *}$ & $0.067^{*}$ \\
\hline & {$[0.054]$} & {$[0.040]$} & {$[0.040]$} & {$[0.037]$} \\
\hline Economic and Administrative Sciences & $0.305^{\star * *}$ & $0.211^{* * *}$ & $0.311^{* * *}$ & 0.045 \\
\hline & {$[0.057]$} & {$[0.041]$} & {$[0.039]$} & {$[0.037]$} \\
\hline Education & $0.263^{* * *}$ & 0.018 & $0.192^{\star * *}$ & $0.164^{\star * *}$ \\
\hline & {$[0.074]$} & {$[0.060]$} & {$[0.058]$} & {$[0.044]$} \\
\hline Prop. of female students in department & $-0.568^{\star * *}$ & $-0.527^{* * *}$ & $-0.472^{\star * *}$ & -0.112 \\
\hline & [0.163] & {$[0.121]$} & {$[0.118]$} & {$[0.115]$} \\
\hline Prop. of female faculty in department & $0.456^{* * *}$ & $0.477^{* * *}$ & $0.480^{* * *}$ & $0.277^{\star * *}$ \\
\hline & {$[0.146]$} & {$[0.103]$} & {$[0.104]$} & {$[0.100]$} \\
\hline Resides in dormitory & $0.159^{\star \star *}$ & 0.04 & $0.054^{\star *}$ & 0.019 \\
\hline & {$[0.039]$} & {$[0.026]$} & {$[0.025]$} & {$[0.022]$} \\
\hline Ankara & $0.182^{* * *}$ & $0.076^{*}$ & $0.208^{* * *}$ & $0.133^{* * *}$ \\
\hline & {$[0.060]$} & [0.043] & [0.038] & {$[0.034]$} \\
\hline Constant & $2.750^{* * *}$ & $1.964^{* * *}$ & $1.868^{* \star *}$ & $2.610^{* * *}$ \\
\hline & {$[0.617]$} & [0.424] & [0.398] & {$[0.333]$} \\
\hline No. of observations & 2745 & 2620 & 2390 & 2588 \\
\hline R-squared & 0.196 & 0.197 & 0.23 & 0.27 \\
\hline
\end{tabular}

Notes: $* * *$ significant at $1 \%, * *$ significant at $5 \%, *$ significant at $10 \%$. Huber-White standard errors reported. Regions indicating permanent place of residence are omitted for brevity. 


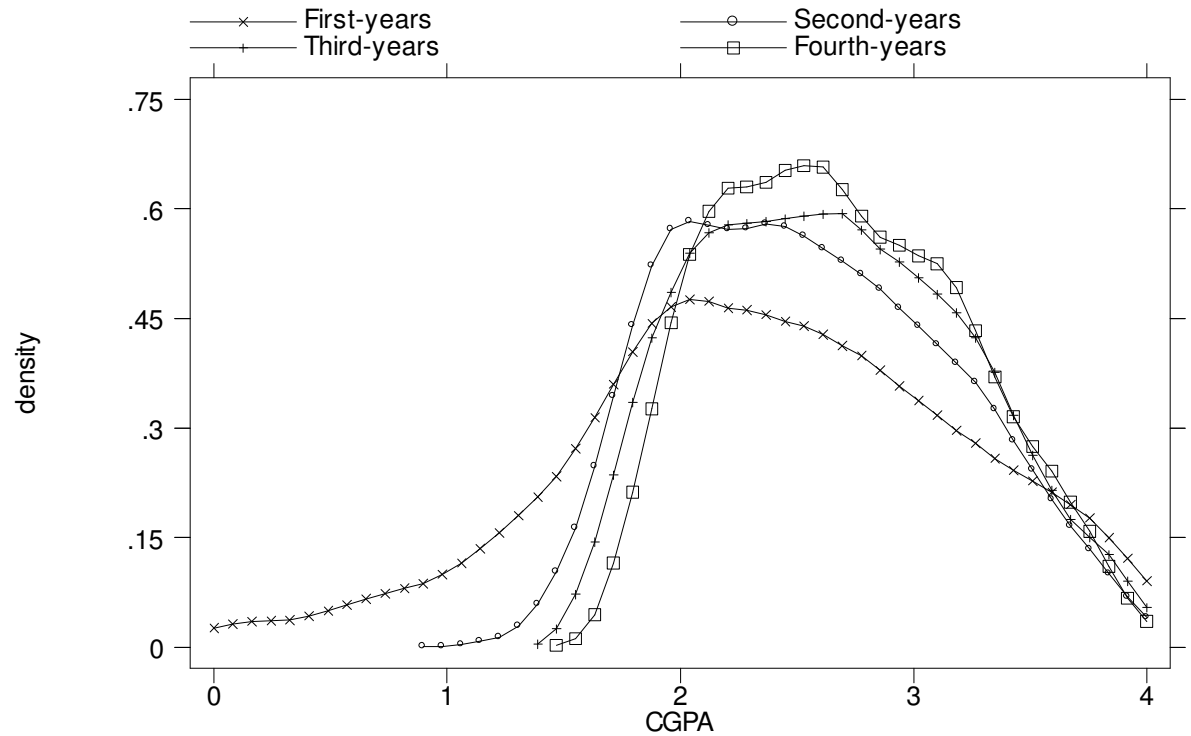

Figure 1: Distribution of CGPA by year

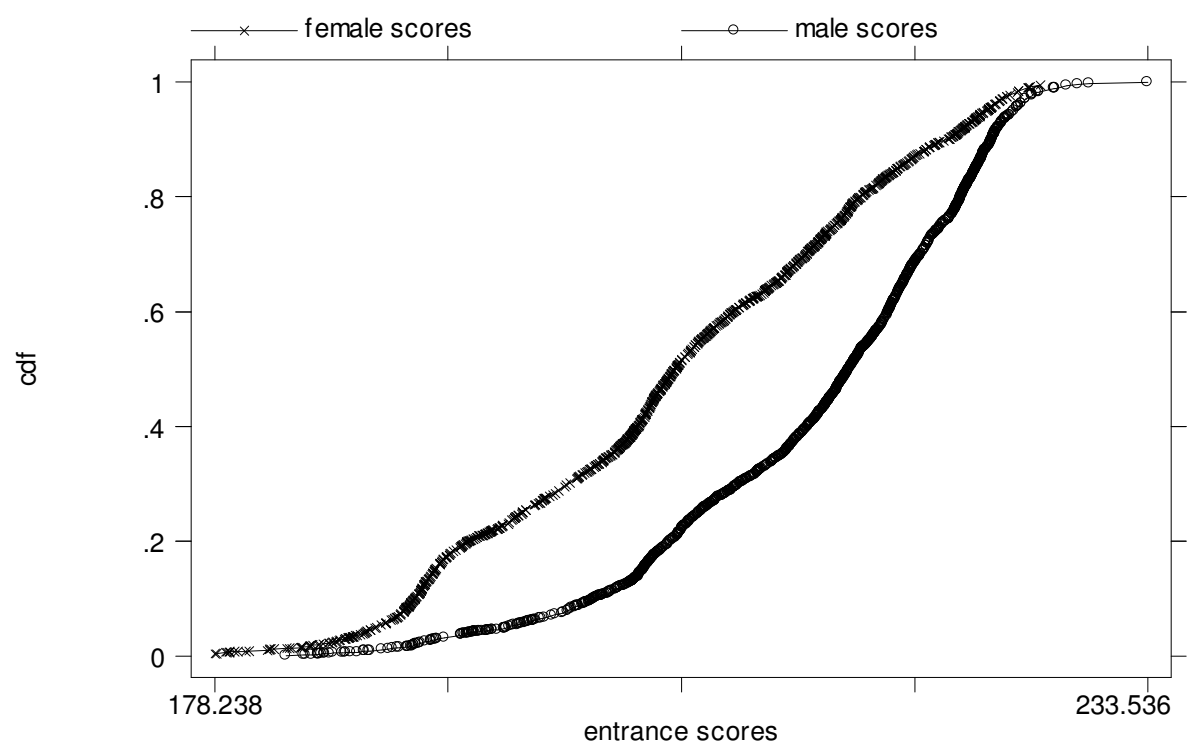

Figure 2A: Cumulative distr.of male and female entrance scores I 


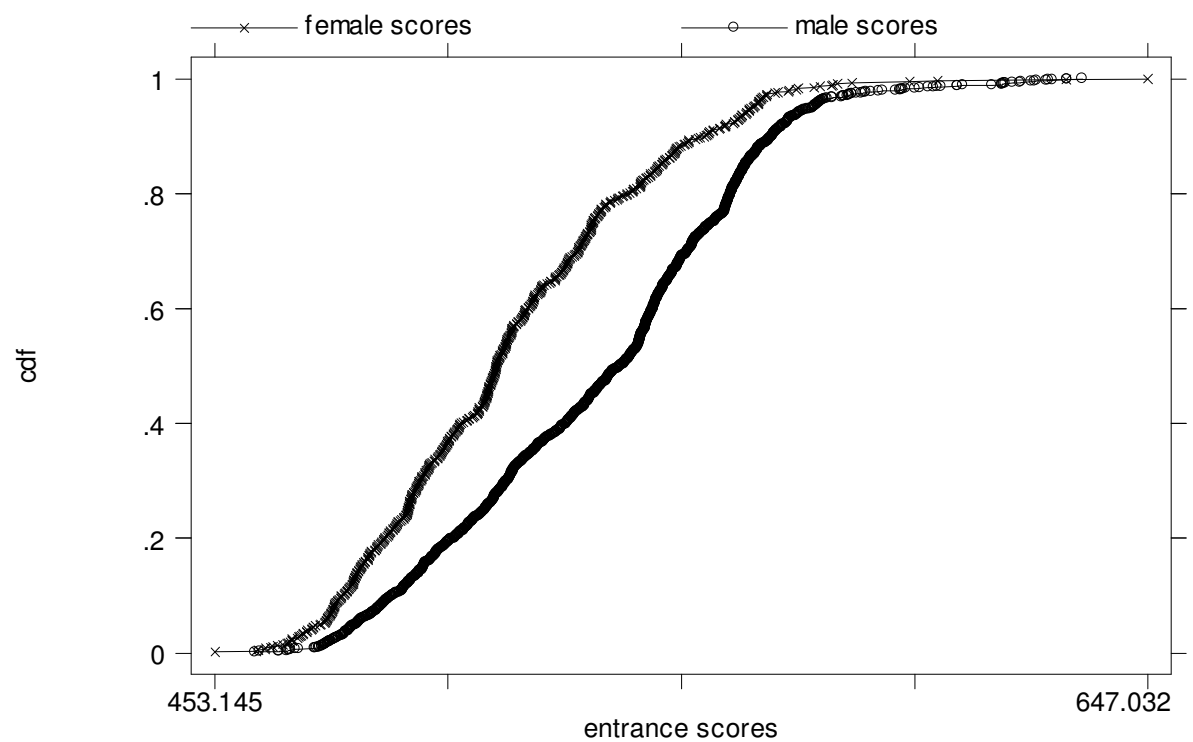

Figure 2B: Cumulative distr.of male and female entrance scores II 